Vietnam Journal of Mechanics, NCST of Vietnam Vol. 25, 2003, No4 (214 - 224)

\title{
LATERAL TURBULENT MIXING FORCES IN THE LONG SHORE CURRENT CALCULATION BY LONGUET-HIGGINS METHOD AND THEIR INFLUENCE ON LONG SHORE SEDIMENT TRANSPORT
}

\author{
NGUYEN MANH Hung \\ Institute of Mechanics, 264 Doi-Can street, Hanoi, Vietnam
}

\begin{abstract}
Longuet - Higgins method for long shore current and Bijker method for sediment transport calculations are world wide used mathematical model in the coastal engineering. When using them, we should image how work the methods and what is sensitivity and influence of each parameters on final results as sediment transport. In this paper, the influences of parameters $N, P$ of lateral turbulent mixing forces on the long shore current and then on the sediment transport are estimated. The Bijker example is used and the computation results are compared with Bijker results for neglecting the lateral turbulent mixing. A field application with appropriate parameters $N$ and $P$ for Le Thuy beach is obtained for verification of long shore current and sediment transport.
\end{abstract}

\section{Introduction}

Shore protection and beach stabilization are major responsibilities of all scientists concerning the coastal environment in general and the marine mechanics in particular. Recently, along the coastline of Vietnam many stretches such as Hai Hau, Hoa Duan, Dinh An beaches are suffering from severe chronic erosion and at the same times some places such as Hai Phong; Cua Lo ports, Dinh An navigational channel etc. are coping with the siltation. The calculations of long shore sediment transport are the main part of all coastal line evolution numerical models which have proven to be powerful tools to assist the most appropriate measure of shore protection. At the same time, based on the theoretical achievements of the concept of wave radiation stresses and long shore current obtained by Longuet-Higgins, Stewart, Battjes [1] the lateral mixing due to turbulence has significant influence on the long shore current profile and, as a results, on the long shore sediment transport.

The aim of this study therefore is to investigate the influences of lateral turbulent mixing forces determined by the parameters $N$ and $P$ on the longshore sediment transport. From the verification with the field measurements (waves, nearshore current and sediment transport) at Le Thuy beach the appropriated values are commented for further use. 
2. Long shore current computation by Longuet-Higgins model and sediment transport computation by Bijker method

\subsection{Forces acting on the water mass in the surf zone}

There are 4 forces acting on the water mass in the long shore direction in the surf zone in particular and in the coastal zone in general:

+ Radiation stress: a pressure force generated by waves in the surf zone.

+ Tidal forces along the coast: the force caused by the influence of the water surface slope along the coast and the inertia of the water mass in the motion of a tidal wave propagating along the coast.

+ The bottom friction force: This friction force is related to the bottom response to the water velocity in the near bottom layer. The friction force is calculated under the combination of wave and current.

+ The turbulent force: the two first above mentioned forces are the driving forces and the third force belongs to a resistance force. The turbulent force acts as both driving and resistance force. It tends to smooth a sharp, steep velocity profile. The lateral turbulent force is the force caused big dispersion of momentum through a vertical plane parallel to the coast (the $y$ axis) resulting from a gradient of velocity in the $x$ direction, $\frac{\partial v}{\partial x}$, where $v$ is the long shore current velocity.

It is convenient to introduce a $\bar{x}$-direction coordinate system: the origin is taken at the coastline and positive $\bar{x}$ is facing seaward. Neglecting the tidal force, the above mentioned forces are discussed in detail by the following:

a. Driving force of radiation stress $\left(S_{x y}\right)$ for long shore current is its cross-shore gradient $\left(\frac{d S_{x y}}{d \bar{x}}\right)$. Differentiating the long shore component of wave radiation stress in term of energy flux gave [1]:

- Outside the surf zone:

$$
\frac{d S_{x y}}{d \bar{x}}=0
$$

- Inside the surf zone:

$$
\frac{d S_{x y}}{d \bar{x}}=\frac{5}{16} \rho \gamma^{2}(g h)^{3 / 2} \frac{\sin \alpha_{0}}{C_{0}} m
$$

where: $C_{0}$ is the wave celerity in deep water, $g$ is the acceleration of gravity, $m$ is the beach slope $(=d h / d x), \gamma$ is the wave breaker index, $\rho$ is the mass density of water and $\alpha_{0}$ is the angle of wave approach in deep water.

b. Bottom friction force: This force is obtained from the equation for combined current and wave bottom friction shear stress as [1]:

$$
\overline{\tau_{c x w}}=\frac{\rho g}{C^{2}}\left[0.75+0.45\left(\xi \frac{U_{b}}{v}\right)^{1.13}\right]
$$


where: $C$ is the Chezy coefficient, $U_{b}$ is the wave-caused water velocity amplitude near the bottom, $v$ is the current velocity averaged over the depth, $\xi$ is the parameter depending on the Chezy coefficient and the bottom wave friction term.

c. Lateral turbulent mixing force: this force is denoted as $\frac{d T_{L}}{d \bar{x}}[2]$

$$
\frac{d T_{L}}{d \bar{x}}=N \rho g^{1 / 2}(m)^{3 / 2} \frac{d}{d \bar{x}}\left[(\bar{x})^{5 / 2} \frac{d v}{d \bar{x}}\right]
$$

where: $T_{L}=h \bar{\tau}_{\ell} ; \bar{\tau}_{\ell}$ is the lateral turbulent eddy stress due to wave, $N$ is a dimensionless, turbulent closure coefficient for lateral wave mixing $(N<0.016$ proposed by Longguet-Higgins (see [2]))

\subsection{Long shore current computation}

The momentum balance equation derived by Longuet-Higgins (see [1]) is:

$$
\frac{d S_{x y}}{d \bar{x}}-\overline{\tau_{c x w}}+\frac{d T_{L}}{d \bar{x}}=0 .
$$

Solving the equation (2.5) with the radiation stress, bottom friction and lateral mixing forces determined by equations $(2.1),(2.2),(2.3),(2.4)$ yields the desired expression for distribution of current velocity along the cross-shore section.

a. Neglecting lateral turbulent mixing:

+ Inside the surf zone [3]:

$$
V_{1}=\frac{5 \pi \sqrt{g}}{8 \sqrt{2}} \frac{\sin \alpha_{0}}{C_{0}} \gamma \frac{C}{\sqrt{f_{w}}} h m
$$

where: $V_{1}$ is long shore current, $f_{w}$ is a dimensionless coefficient depending on bottom roughness and the amplitude of the water displacement near the bottom.

+ Outside the surf zone:

$$
V_{1}=0 .
$$

b. Reference long shore current velocity:

Again neglecting lateral turbulent mixing stresses, the long shore current at the breaker line $V_{b r}$ can be used as a reference velocity. It becomes from equation (2.6) after taking $h=h_{b r}$.

$$
V_{b r}=\frac{5 \pi \sqrt{g}}{8 \sqrt{2}} \frac{\sin \alpha_{0}}{C_{0}} \gamma \frac{C}{\sqrt{f_{w}}} h_{b r} m .
$$

c. With the lateral turbulent mixing:

+ Dimensionless long shore current: Longuet-Higgins introduced the dimensionless variables, $X$ and $V$ as following [1], [2]:

$$
X=\frac{\bar{x}}{x_{b r}} \quad V=\frac{v}{V_{b r}} .
$$


The dimensionless parameter $P$ represents the relative importance of lateral turbulent mixing of the wave orbital motion to the bottom friction resistance:

$$
P=\frac{N \pi m}{C_{f} \gamma}
$$

where $C_{f}$ is a boundary resistance coefficient due to both wave and long shore current.

Longuet-Higgins has solved equation (2.5) with the dimensionless parameters $X$, $V$ and $P$ and obtained the following results [1], [2]:

+ In general, $P \neq 0.4$

$$
\begin{aligned}
V & =A X+B_{1} X^{P_{1}} \quad 0<X<1 \quad \text { (inside breaker zone) } \\
V & =B_{2} X^{P_{2}} \quad X>1 \quad \text { (outside breaker zone) } \\
A & =\frac{1}{\left(1-\frac{5}{2} P\right)} \\
P_{1} & =-\frac{3}{4}+\sqrt{\frac{9}{16}+\frac{1}{P}} \\
P_{2} & =-\frac{3}{4}-\sqrt{\frac{9}{16}+\frac{1}{P}} \\
B_{1} & =\frac{P_{2}-1}{P_{1}-P_{2}} A \\
B_{2} & =\frac{P_{1}-1}{P_{1}-P_{2}} A \\
\text { ularity, } & P=0.4 \\
V & =\frac{10}{49} X-\frac{5}{7} X \ln X \quad 0<X<1 \quad \text { (inside breaker zone) } \\
V & =\frac{10}{49} X-\frac{5}{7} X \ln X \quad X>1 \quad \text { (outside breaker zone) }
\end{aligned}
$$

+ In singularity, $P=0.4$

\subsection{Sediment transport computation}

Bed load sediment transport by Bijker (see [3]) is:

$$
Q T_{b}=5 D_{50} \sqrt{g} \frac{V}{C} \exp \left[\frac{-0.27 \Delta D_{50} \rho g}{\mu \overline{T_{c w}}}\right]
$$

where: $D_{50}$ is mean $(50 \%)$ sediment grain size, $V$ is current velocity (by wave, wind...), $\Delta$ is the relative sediment density,

$$
\Delta=\frac{\rho_{s}-\rho}{\rho}
$$


$\rho_{s}$ is the mass density of the sediment, $\mu$ is the ripple factor, $\bar{\tau} c w$ is the current and wave shear stress,

$$
\begin{aligned}
\overline{\tau_{c w}} & =\tau_{c}+\frac{1}{2} \overline{\tau_{w}} \\
\tau_{c} & =\frac{\rho g V^{2}}{c^{2}} \\
\overline{\tau_{w}} & =\tau_{c}\left(\xi \frac{U_{b}}{v}\right)
\end{aligned}
$$

where: $\tau_{c}$ is the bed shear due to current alone, $\overline{\tau_{w}}$ is the bed shear due to wave alone.

For the suspended load sediment transport $\left(Q T_{s}\right)$, Bijker used Einstein integrals $I_{1}$ and $I_{2}$ which result in the simple relationship [3]:

$$
Q T=Q T_{s}+Q T_{b}=Q T_{b}(1+1.83 Q)
$$

where $Q=I_{1} \ln (33 h / \tau)+I_{2} ; I_{1}, I_{2}$ are Einstein integrals, $\tau$ is bed roughness.

A table of the values of Einstein integrals is ready as the input file for computation.

3. Long shore current, sediment transport computations and application for Le Thuy beach

\subsection{Bijker example}

The following example is intended to demonstrate two calculations: First, computations of long shore current in the case of neglecting lateral mixing stresses and including lateral mixing stresses with different dimensionless mixing parameters $P$ are illustrated. Second, the influence of different cross shore distributions of current to sediment transport is demonstrated by computing sediment transport distribution using Bijker method by various long shore currents. The input offshore wave and beach bathymetry conditions are assumed to be the same one in Bijker example [3]. These are:

Wave period, $T$

Wave height, $H_{0}$

Approach angle, $\alpha_{0}$

Breaker index, $\gamma$

Beach slope, $m$

Bottom roughness, $r$

Boundary resistance coefficient, $C_{f}$

Sand mean diameter, $D_{50}$

Water density, $\rho$

Sand density, $\rho_{s}$

Particle fall velocity, $W$
$: 7.0 \mathrm{~s}$

$: 2.0 \mathrm{~m}$

$: 30^{\circ}$

$: 0.8$

$: 0.01$

: $0.06 \mathrm{~m}$

$: 0.01$

: $0.200 \mathrm{~mm}$

: $1000 \mathrm{~kg} / \mathrm{m}^{3}$

: $2650 \mathrm{~kg} / \mathrm{m}^{3}$

: $0.0252 \mathrm{~m} / \mathrm{s}$ 
The cross shore beach section is chosen with the step of $25 \mathrm{~m}$ from the shoreline to $500 \mathrm{~m}$ seaward corresponding depth step of $0.25 \mathrm{~m}$ from $0 \mathrm{~m}$ to $5 \mathrm{~m}$. The computation starts with the wave transformation calculation [3]. For each vertical, the obtained wave height is used to check the breaker index. The current computations are followed the equation (2.6)-(2.19) with the computing distribution of long shore current velocity without lateral mixing stresses on the first step. Lastly the distribution of long shore current with lateral mixing stresses for all the section is obtained. The sediment transport for each vertical is calculated by Bijker method [3]. The cross shore distribution of the calculated current velocities is illustrated in the figure 1 .

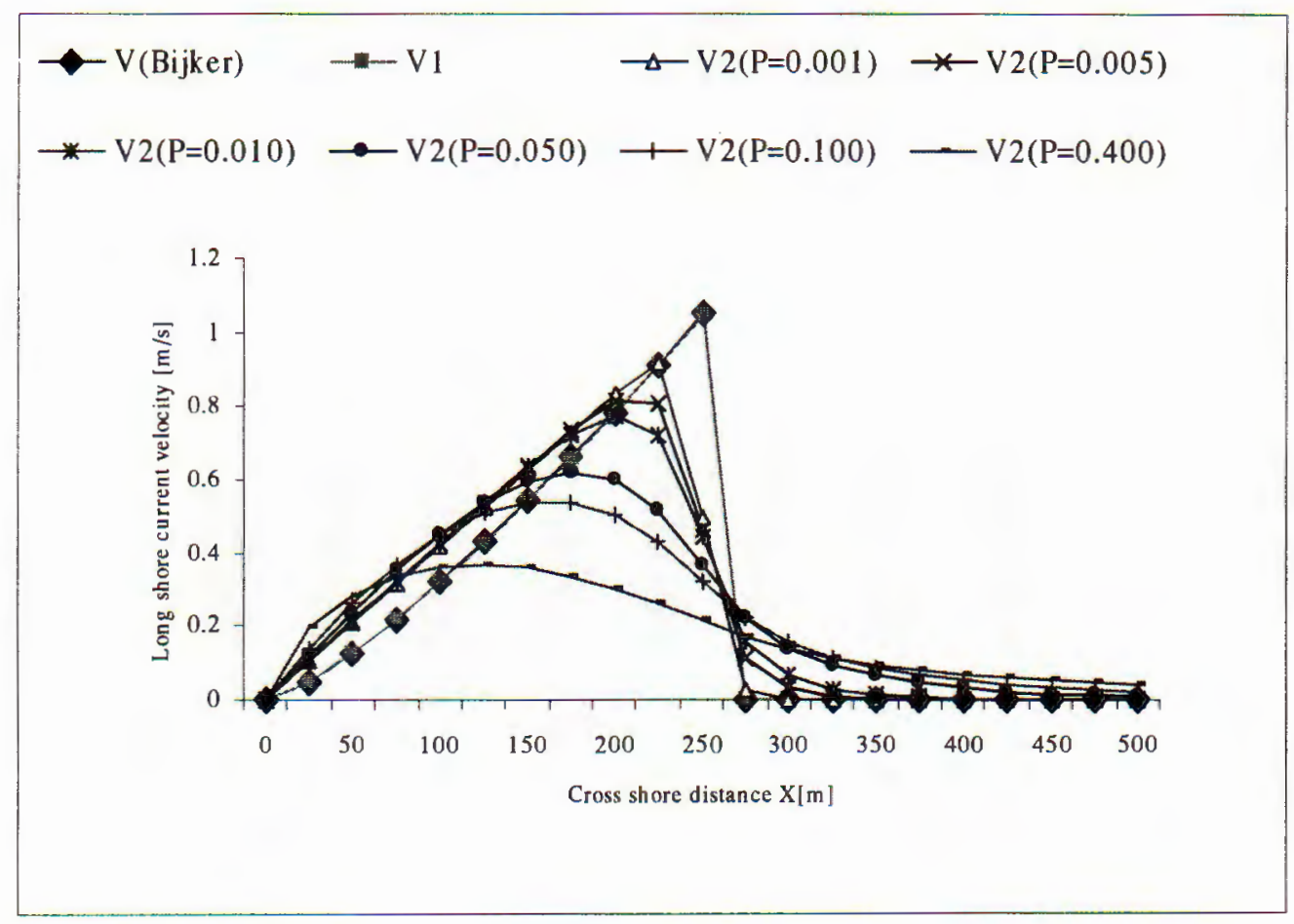

Fig. 1. Long shore current calculated by Longuet-Higgins method with various $P$ values for the Bijker example

$V_{1}$ is the current velocity obtained by the equation (2.6)-(2.8), corresponding to the case of no lateral mixing stresses. $V_{2}$ is calculated with various dimensionless mixing parameters $P$ ( $P$ from 0.001 to 0.4 and $N$ is from 0.00025 to 0.10186 respectively). The current calculated by Bijker [2] (V. Bijker) corresponding to the case of no lateral mixing stresses is also shown in the figure 1 and it has the same magnitude as $V_{1}$. Figure 1 very clearly demonstrates the smoothing effect of lateral stresses. The maximum long shore current velocity occurs at the breaker line in the case without lateral mixing. Taking larger $P$ values gives more lateral turbulent mixing to smooth and spread the $V_{1}$ profile across the surf zone and beyond the 
breaker.

Figure 2 shows the results of sediment transport computing by Bijker method and total long shore sediment transport for the cross shore section based on different current profiles depending on the various mixing parameters $P$. According to Figure 2 the total long shore sediment transport for various current profiles does not change so much. In the case of very small $P(P=0.001)$ the integrated long shore sediment transport for cross shore section increases in comparing with the case of neglecting the lateral mixing because of the spread effect which increases the current velocity inside, and outside the breaker zone. In general the total long shore sediment transport does not change so much depending on the various mixing parameters $P$ because of the following reasons:

+ The integrated volume of longshore current velocities and the cross shore area which is defined as total long shore sediment transport changes not so much,

+ Because of the spread effect which increases the current velocity near shore line and results to the increasing of total long shore sediment transport.

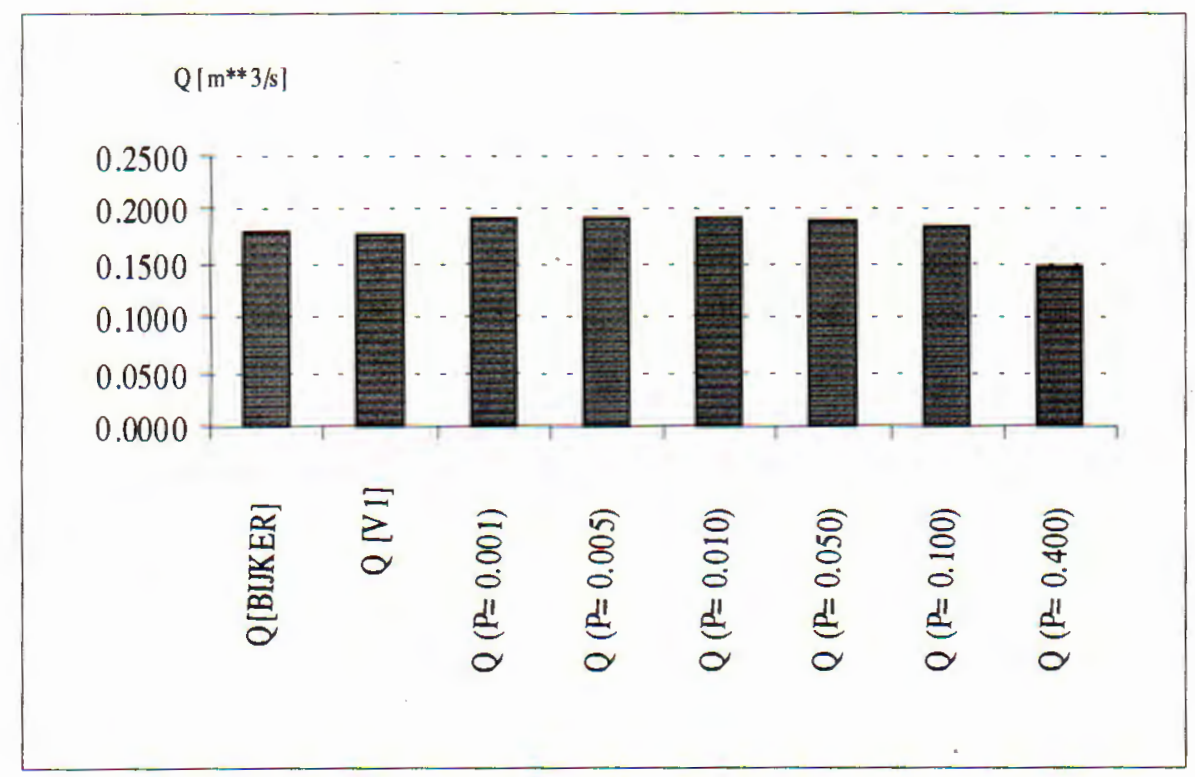

Fig. 2. Total long shore sediment transport calculated by Longuet-Higgins method with various $P$ values for the Bijker example

\subsection{A field application at Le Thuy beach}

The coastal line of Le Thuy - Quang Binh province is Northwest-Southeast oriented with rather strait line. The bathymetry is quite simple with the depth contours paralleled to the shore line. The bottom soil consists of fine and middle sand. The data on wave, current and partly on sediment transport are available during the period of 1992-1995 (National Marine Program [4]) and 1996-1997 (Research Program of the Cross-section of Tongking Gulf; Sub-Institute of Marine Mechanics [5]). The computation is made for the duration from $16 \mathrm{~h} 6 / \mathrm{I} / 1995$ to $10 \mathrm{~h} 11 / \mathrm{I} / 1995$. During 
the computation period two wave recorders (at the depth of $20 \mathrm{~m}$ and $1.5 \mathrm{~m}$ ) were exploited and the long shore current was measured each 3 hours by floating method. A sediment trap was operated at the depth of $1.5 \mathrm{~m}$ for the recording duration from $11 \mathrm{~h} 8 / \mathrm{I}$ to $11 \mathrm{~h} 9 / \mathrm{I}$.

The wave at the depth of $20 \mathrm{~m}$ was the input offshore wave for each 3 hour periods. The other input parameters are:
Breaker index, $\gamma$
$: 0.8$
Beach slope, $m$
$: 0.01$
Bottom roughness, $r$
: $0.06 \mathrm{~m}$
Boundary resistance coefficient, $C_{f}: 0.01$
Sand mean diameter, $D_{50}$
: $0.400 \mathrm{~mm}$
Water density, $\rho$
: $1000 \mathrm{~kg} / \mathrm{m}^{3}$
Sand density, $\rho_{s}$
: $2650 \mathrm{~kg} / \mathrm{m}^{3}$
Particle fall velocity, $W$
: $0.0252 \mathrm{~m} / \mathrm{s}$

Figure 3 depicts the long shore current calculated without lateral mixing and with the various $P$ values in the case with lateral mixing for $16 \mathrm{~h} 9 / \mathrm{I} / 1995$. The cross shore distribution of long shore sediment transport for the same time is tabulated in the table 1.

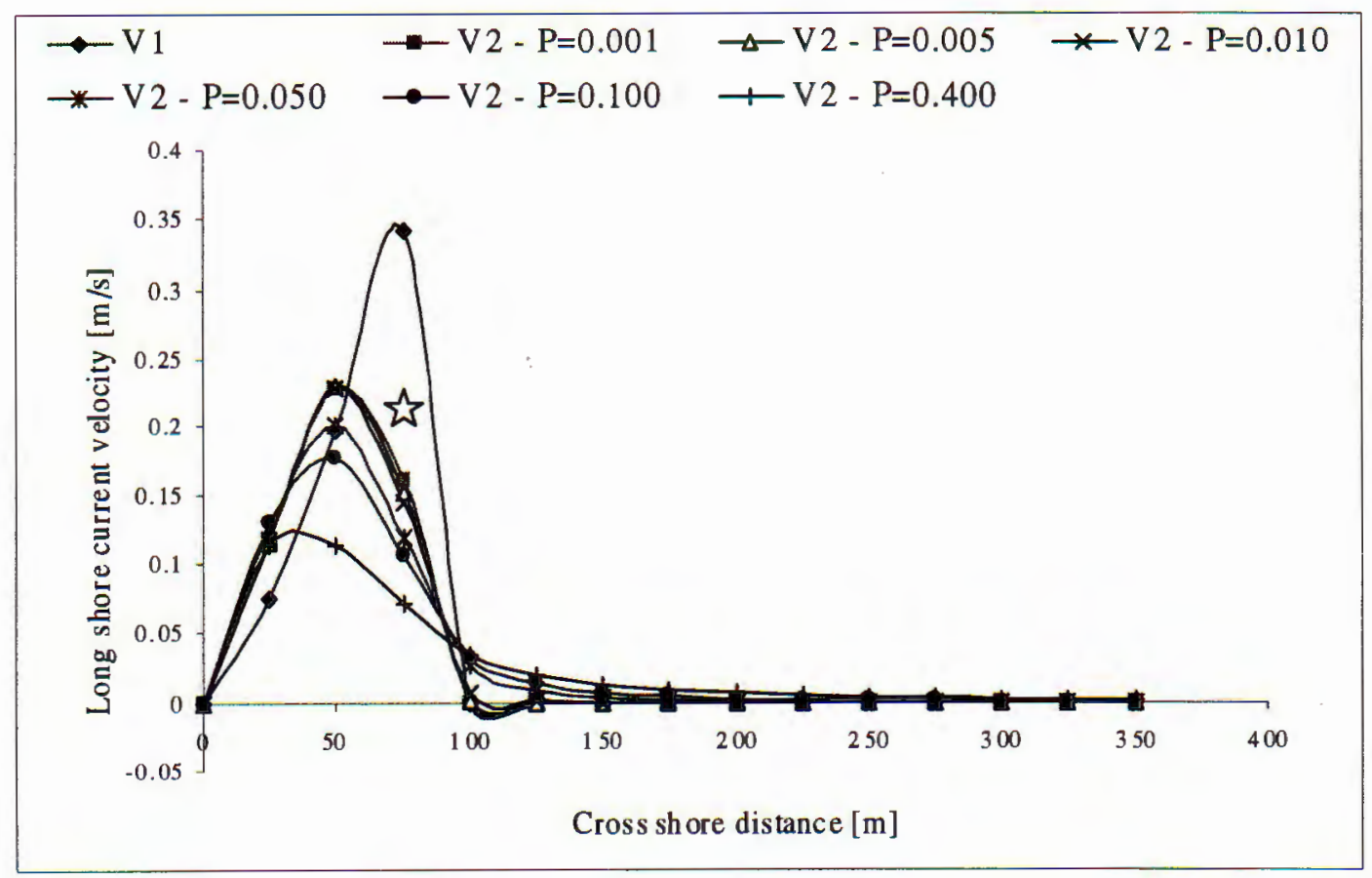

Fig. 3. Long shore current velocity calculated by Longuet-Higgins method with various $P$ values for Le Thuy beach $16 \mathrm{~h} 9 / 1 / 1995$, (star) is the measurement value 
According to the figure 3 , the maximum long shore current (North directed) belongs to the first case (without lateral mixing) with the value of about $0.35 \mathrm{~m} / \mathrm{s}$. The currents in the second case are changed by various dimesionless $P$ values. The measurement current velocity (denoted by a star in the figure) is $0.21 \mathrm{~m} / \mathrm{s}$. The long shore current and sediment transport calculations are operated for 7 cases from $16 \mathrm{~h}$ 6/I to $10 \mathrm{~h} 11 / \mathrm{I}$ and the most fitting $P$ values with the measurement is $P=0.05$.

Tab. 1. The cross shore distribution of long shore sediment transport $Q\left[\mathrm{~m}^{3} / \mathrm{s}\right] \times 10^{-3}$ with various $P$ values at Le Thuy beach $16 \mathrm{~h} 9 / 1 / 1995$ (hdeep $=0.57 \mathrm{~m} ;$ Tdeep $=6.0 \mathrm{~s}, \mathrm{Zdeep}=\mathrm{E}$ )

\begin{tabular}{|c|c|c|c|c|c|c|c|}
\hline $\begin{array}{l}\text { Cr.dis } \\
{[\mathrm{m}]}\end{array}$ & $\begin{array}{l}\text { Depth } \\
{[\mathrm{m}]}\end{array}$ & $\begin{array}{c}Q \\
P=0.001\end{array}$ & $\begin{array}{c}Q \\
P=0.005\end{array}$ & $\begin{array}{c}Q \\
P=0.010\end{array}$ & $\begin{array}{l}Q \\
P=0.0050\end{array}$ & $\begin{array}{c}Q \\
P=0.100\end{array}$ & $\begin{array}{c}Q \\
P=0.400\end{array}$ \\
\hline 0 & 0.00 & 0.4007 & 0.4050 & 0.4104 & 0.4441 & 0.4570 & 0.3950 \\
\hline 25 & 0.25 & 2.2581 & 2.2751 & 2.2720 & 2.0752 & 1.8737 & 1.2866 \\
\hline 50 & 0.50 & 3.9858 & 3.8625 & 3.7608 & 3.2018 & 2.7923 & 1.8020 \\
\hline 75 & 0.75 & 2.1302 & 2.0292 & 2.0145 & 2.0347 & 1.9645 & 1.5118 \\
\hline 100 & 1.00 & 0.0040 & 0.0390 & 0.1282 & 0.6423 & 0.8901 & 1.0314 \\
\hline 125 & 1.25 & 0.0052 & 0.0052 & 0.0159 & 0.2683 & 0.4937 & 0.7910 \\
\hline 150 & 1.50 & 0.0065 & 0.0065 & 0.0065 & 0.1389 & 0.3195 & 0.6614 \\
\hline 175 & 1.75 & 0.0078 & 0.0078 & 0.0078 & 0.0771 & 0.2145 & 0.5529 \\
\hline 200 & 2.00 & 0.0090 & 0.0090 & 0.0090 & 0.0454 & 0.1489 & 0.4646 \\
\hline 225 & 2.25 & 0.0100 & 0.0100 & 0.0100 & 0.0279 & 0.1059 & 0.3911 \\
\hline 250 & 2.50 & 0.0109 & 0.0109 & 0.0109 & 0.0178 & 0.0770 & 0.3311 \\
\hline 275 & 2.75 & 0.0116 & 0.0116 & 0.0116 & 0.0130 & 0.0572 & 0.2821 \\
\hline 300 & 3.00 & 0.0129 & 0.0129 & 0.0129 & 0.0129 & 0.0451 & 0.2531 \\
\hline 325 & 3.25 & 0.0147 & 0.0147 & 0.0147 & 0.0147 & 0.0377 & 0.2376 \\
\hline 350 & 3.50 & $* * * * * *$ & $* * * * * *$ & $* * * * * *$ & $* * * * * *$ & $* * * * * *$ & $* * * * * *$ \\
\hline \multicolumn{2}{|c|}{ Total sed. } & 8.86730 & 8.6992 & 8.6853 & 9.0140 & 9.4770 & 9.9918 \\
\hline
\end{tabular}

Table 2 shows the amounts of sediment caught by the sediment traps operated at the depth of $1.5 \mathrm{~m}$ (station LT3 [4]). Based on the table 2, the average amount of sediment transport to the North for the measured layer from $10 \mathrm{~cm}$ to $40 \mathrm{~cm}$ above the sea bottom is approximately 230 grams per day. Based on the area of the sediment trap (the diameter catching circle is $0.005 \mathrm{~m}$ ) and the suspended sediment transport is $1 / 3$ of total sediment transport (for the sand bottom with grain size of $0.0004 \mathrm{~m}$ ) the total North directed sediment transport is about $3.3 \mathrm{~m}^{3}$ per day. For the sector from $75 \mathrm{~m}$ to $100 \mathrm{~m}$ from the coastal line the amount of sediment transport is approximately $72 \mathrm{~m}^{3}$ per day. Based on the computation of sediment transport (the total sediment transport for the whole cross shore section is tabulated on the table 2) the sediment transport for the section from $75 \mathrm{~m}$ to $100 \mathrm{~m}$ far from the shoreline is $0.0006423 \mathrm{~m}^{3} / \mathrm{s}$ which results to the total sediment transport of $55 \mathrm{~m}^{3}$ 
per day. It can be seen that the difference of the measured and calculated sediment transport volume per day is in the acceptable range.

Tab. 2. Amounts of sediment filled into sediment traps at Le Thuy coastal station [4]. Recording duration $11 \mathrm{~h} 8 / \mathrm{I}-11 \mathrm{~h} 9 / \mathrm{I}$

\begin{tabular}{|c|c|c|c|}
\hline $\begin{array}{c}\text { Number of sand } \\
\text { traps }\end{array}$ & $\begin{array}{l}\text { Elevation above the } \\
\text { sea bottom }[\mathrm{m}]\end{array}$ & $\begin{array}{l}\text { Sediment amount } \\
\text { [grams] }\end{array}$ & $\begin{array}{c}\text { Direction of } \\
\text { sediment transport }\end{array}$ \\
\hline 16 & 0.4 & 125.417 & $\mathrm{~N}$ \\
\hline 23 . & 0.4 & 24.954 & S \\
\hline 17 & 0.2 & 270.482 & $\mathrm{~N}$ \\
\hline 21 & 0.2 & 141.0 .2 & $\mathrm{~S}$ \\
\hline 11 & 0.1 & 290.389 & $\mathrm{~N}$ \\
\hline 2 & 0.1 & 226.426 & $\mathrm{~S}$ \\
\hline
\end{tabular}

It is worth to note that the North directed sediment transport at Le Thuy coastal zone takes place only during Summer time - SW monsoon and during the transition time from Summer to Winter and inverse with the deep sea wave angle band from $\mathrm{SE}$ to E. For the whole year the predominated wave is from the Northeast monsoon (NE direction). According to the computation of long-shore transport rate by routine procedure of GENESIS model by SEDTRAN program the South net sediment transport is about $430,000 \mathrm{~m}^{3}$ per year while the North directed sediment transport is $93,000 \mathrm{~m}^{3}$ per year [5].

\section{Conclusion}

Longguet-Higgins method is reasonably accepted in long shore current calculation for near shore study in general and sediment transport calculation in particular. The range of dimensionless parameter $P$ is from 0.001 to 0.4 , the good fitting value of $P$ to measurement at Le Thuy beach is $P=0.05$ and $N=0.013$.

The total long shore sediment transport for various current profiles according to various lateral mixing parameters $P$ and $N$ does not change so much. According to the annual estimated long shore transport by Bijker example, the yearly volume of long shore sediment transport decreases about $25 \%$ when the lateral mixing parameter $P$ increases from 0.001 to 0.4 . The spreading effect decreases the maximum current velocity at the breaker line and at the same time increases the current velocity inside and out side the breaker line. In order to increase the accuracy of the longshore sediment transport calculation, more effort should be focussed on determination of sediment properties and on the near shore wave calculations (wave breaker line, wave radiation stresses etc...).

The field application at Le Thuy beach shows the reasonable calculation results comparing with the measurements. 
The author wishes to direct his thanks to Professor Z. Pruszak (from Institute of Hydro-engineering, Gdansk) for many valuable guidances and discussions.

The paper was partly supported by fundamental research project "Marine Hydraudynamics and Environment No 321501".

\section{REFERENCES}

1. Waves on Beaches and Resulting Sediment transport. Edited by R. E. Meyer. Academic Press New York 1972.

2. Surf zone current. Volume I, State of Knowledge. By David R. Basco. CERC 1982.

3. Local training of IHR staff member. The Hanoi lecture notes on coastal engineering. Delft Hydraulics 10/1989.

4. Survey report of the National project KT03.01. National Marine program KT.03. Data proceeding of the field surveys 1994-1995. Chapter 2 and 3: Wave, current and sediment transport data analysis. Sub-Institute of Marine Mechanic, Hanoi, 1995, pp. 1 - 95 (in Vietnamese).

5. Nguyen Manh Hung, Nguyen Thanh Co. Longshore sediment transport along the coast of Vietnam, National Marine project, KHCN06 10. Institute of Mechanics, Hanoi 2001. pp1-269 (in Vietnamese)

Received May 5, 2003

CÁC LỰC TRAO ĐỔI RỐI NGANG TRONG MÔ HÌNH TÍNH DÒNG CHẢY DỌC BỜ CƯA LONGUET-HIGGINS VÀ ÁNH HƯờNG CỦA CHÚNG ĐẾN DÒNG VẬN CHUYỂN BÙN CÁT DỌC BÒ

Mô hình tính dòng chảy sóng dọc bờ của Longuet-Higgins và phương pháp tính dòng vận chuyển bùn cát của Bijker hiện đang dược sử dụng rộng rãi trong thiết kế các công trình ven bờ và bảo vệ bò̀ biển. Tuy nhiên như đã biết trong tính toán dòng cháy sóng dọc bờ hệ số trao đổi rối ngang do sóng $(N$ và $P)$ ành hường đến tác động của chuyển động quỹ đạo của hạt nước trong sóng lên đáy biển và do vậy gây ra sự biến đổi mạnh phân bố của tốc độ dòng chảy sóng trong vùng sóng đổ. Hậu quả của sự biến đổi này là gây ra biến đổi lượng vận chuyển bùn cát do sóng. Mục tiêu của bài báo là đánh giá sự biến đổi của phân bố dòng vận chuyển bùn cát và tổng lượng vận chuyển bùn cát trong các điều kiện trường sóng nhất định khi thay đồi các hệ số trao đổi rối ngang khác nhau. Đã tính toán cho hai trường hợp: trường hợp bài toán chuẩn của Bijker và trường hợp đo đạc thực tế tại khu vực ven bờ Lệ Thuỷ - Quảng Bình có so sánh với kết quả đo dòng chảy ven và số liệu bùn cát thu được bằng bẫy bùn cát. Kết quả cho thấy mặc dù phân bố dòng chảy thay đổi rất mạnh khi thay đổi hệ số trao đổi rối ngang nhưng tổng lượng vận chuyển bùn cát dọc bờ cho toàn bộ mặt cắt từ bờ ra khơi thay đổi không đáng kể. 